\title{
Design of the operation of a rotating machine for the acquisition of multi-view stereoscopic images for the $3 \mathrm{D}$ reconstruction of objects
}

\section{Diseño de la operación de una máquina rotativa de adquisición de múltiples vistas de imágenes estereoscópicas para la reconstrucción 3D de Objetos}

\author{
CORONA-PATRICIO, Cesar Agustin*1 \& RETA, Carolina ${ }^{2}$ \\ ${ }^{1}$ CONACYT-CIATEQ A. C. PICYT. San Agustín del Retablo 150, Constituyentes Fovissste, C.P. 76150 Santiago de Queretaro, \\ Qro., Mexico. \\ ${ }^{2}$ CONACYT-CIATEQ A. C. Department of IT, Control, and Electronics. Manzana 5, Lote 1, entre Gaza 30 y 40, C.P. 42162 \\ San Agustin Tlaxiaca, Hgo., Mexico.
}

\author{
ID $1^{\text {st }}$ Author: Cesar-Agustin, Corona-Patricio / ORC ID: 0000-0002-9105-9483, CVU CONACYT ID: 874048 \\ ID $1^{\text {st }}$ Co-author: Carolina, Reta / ORC ID: 0000-0002-0843-129X, CVU CONACYT ID: 235176
}

DOI: $10.35429 /$ JOCT.2021.15.5.29.36

Received March 15, 2021; Accepted June 28, 2021

\begin{abstract}
This work presents a machine to locate a stereoscopic camera in different positions around an object to acquire a sequence of images that allows the reconstruction of such object through artificial vision algorithms. The GEMMA guide was used to define the modes of operation of the proposed machine. In addition, the mechanical and electronic elements that make up the machine and the programming logic for its control with PLC were also defined. It was demonstrated using a graphical interface that the mode of operation of the machine is carried out satisfactorily. Additionally, this work presents synthetic image results to represent a sequence of images acquired from different points of view considering different levels of elevation of the camera, showing the type of results obtained with the proposed machine.
\end{abstract}

Automation and control, Image acquisition, Multiple views, Stereo camera, 3D reconstruction

\begin{abstract}
Resumen
En este trabajo se propone una máquina que permite posicionar una cámara estereoscópica en diferentes ubicaciones alrededor de un objeto para adquirir una secuencia de imágenes que al ser procesada por algoritmos de visión artificial permita la reconstrucción de dicho objeto. Para definir los modos de operación de la máquina propuesta se usó la guía GEMMA. También, se definieron los elementos mecánicos y electrónicos que componen la máquina, así como la lógica de programación para su control con PLC. Se demostró mediante una interfaz gráfica que el modo de operación de la máquina es llevado a cabo de manera satisfactoria. Adicionalmente, se presentaron resultados de imágenes sintéticas para representar una secuencia de imágenes adquirida desde diferentes puntos de vista considerando diferentes niveles de elevación de la cámara. Esto permitió mostrar el tipo de resultados que pueden obtenerse con la máquina propuesta.
\end{abstract}

Automatización y control, Adquisición de imágenes, Múltiples vistas, Cámara estéreo, Reconstrucción 3D

Citation: CORONA-PATRICIO, Cesar Agustin \& RETA, Carolina. Design of the operation of a rotating machine for the acquisition of multi-view stereoscopic images for the 3D reconstruction of objects. Journal of Computational Technologies. 2021. 5-15: 29-36

\footnotetext{
* Author Correspondence: (e-mail: cesar.corona@ ciateq.edu.mx)

$\dagger$ Researcher contributing as first author.
} 


\section{Introduction}

3D reconstruction is a set of techniques that allow inferring the geometric and photometric information of a physical object from one or more images. The reconstruction of objects has many applications, including cultural heritage preservation, medicine, engineering, content creation for virtual environments, among others (Durou et al., 2020).

This paper covers the subject of image acquisition for 3D reconstruction from multiple views captured with a stereoscopic camera. Figure 1 shows the image capturing process, in which a camera moves around an object to generate images from multiple viewpoints. The captured images are obtained in the digital format provided by the stereoscopic camera. This process is fundamental to obtain the necessary information for the 3D reconstruction process.

In the literature exists different ways to capture the multiples views of an object. One way is having the camera fixed and rotate the object around it (Sheng et al., 2018; Wang \& Hauser, 2019; Wu et al., 2019); the other option is to keep the object fixed and rotate the camera around it (Deris et al., 2017; Yücer et al., 2016). A limitation of the first approach is that a homogeneous background must be placed behind the object to have good reconstruction results.

The captured images can be processed by computer vision algorithms for 3D object reconstruction. There is free software such as Regard3D (Regard3D, 2021), OpenSFM (OpenSFM, 2021), and Meshroom (Allice Vision, 2021) that can be employed to obtain the 3D model of the object.

There are also approaches to capture the multiple views with multiple cameras (KaiBrowne et al., 2016; Li et al., 2019; Wu et al., 2019). However, similar results can be achieved efficiently and economically by employing only one camera.

A relevant work in the literature related to multi-view object image acquisition machines is OpenScan (OpenScan, 2021).
This is a DIY 3D scanner which is small (less than $50 \mathrm{~cm}$ ), inexpensive, open design, Arduino or Raspberry Pi-based, that helps capture images to apply the 3D reconstruction process. OpenScan is designed so that the object to be reconstructed is rotated $360^{\circ}$ in 3 different elevations, keeping fixed an RGB camera. Its main disadvantage is that the objects it can scan are small in size and must be light in weight. Other similar work for multi-view image acquisition can be found in (Collins et al., 2019; Emmitt et al., 2021; Evgenikou \& Georgopoulos, 2015).

The rotating image acquisition machine proposed in this paper uses a stereoscopic camera, which is rotated around the object at three elevation levels. The advantage of the proposed machine is that it can scan mediumsize objects and does not require placing any homogeneous background behind the objects.

This paper is organized as follows. In Section 2, the mechanical design of the image acquisition machine and the electronic design and control of the machine are proposed. In Section 3, the graphical interface for the machine operation and the visual results of the image acquisition process are presented. In Section 4, as Appendix, supplementary information regarding the control design of the proposed machine is presented. Finally, Section 5 presents the conclusions of the proposed work and discusses future work.

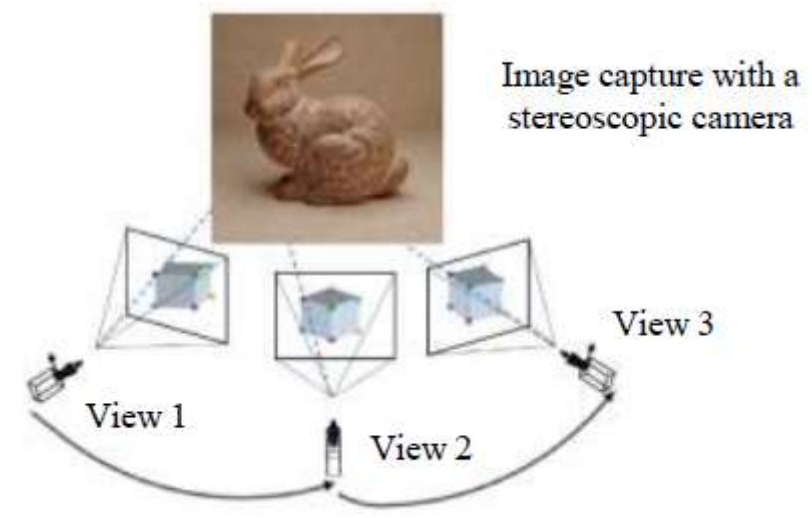

Figure 1 Multi-view image capturing process Source: Own elaboration based on images of Cordes et al., 2012; Yilmaz \& Karakus, 2013; Stanford University, 2014 


\section{Proposed method}

In this work, a positioning machine that allows moving a stereoscopic camera so that visual characteristics of an object can be obtained from different viewpoints is proposed. The purpose of using this machine is to acquire the necessary information of the object for its 3D reconstruction. The main contents of this work: the mechanical design and the electronic design and control of the proposed machine, are presented in the following sections.

\subsection{Mechanical design of the image acquisition machine}

The proposed machine is presented in Figure 2. The camera is mounted on a base, resting on a rotary table. Motor M1 allows placing the camera around the object, and motor M2 allows setting the camera's elevation. Sensors S1, S2, and S3 indicate the elevation levels of the camera. Sensors S0 and SF allow setting the initial position of the sequence to be performed in automatic mode. A proximity sensor S4 is used on the camera to detect strange objects near the camera that may introduce noise or collide with the camera. Figures $2 a$ and $2 b$ show the top view and frontal view of the machine, respectively. Figure $2 \mathrm{c}$ lists all the components of the proposed machine.

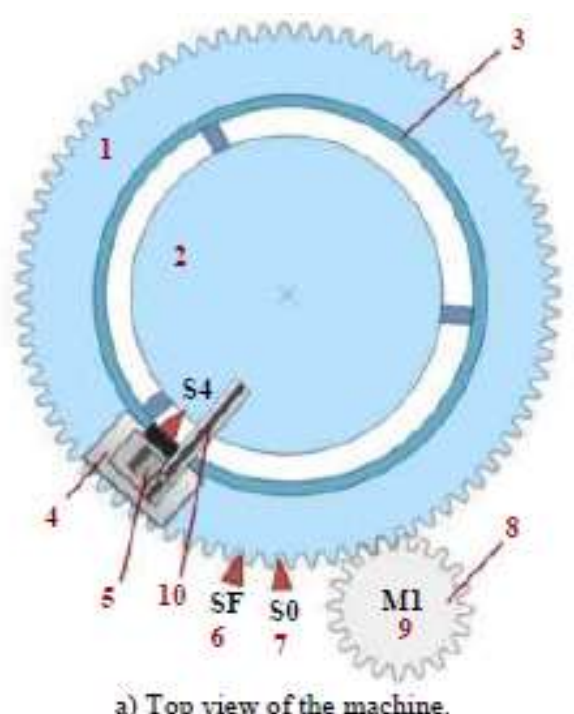

1. Hollow rotary table

2. Base to place the object

3. Support for rotary table

4. Base where the camera can move $360^{\circ}$

5. Bipolar DC stepper motor (M2)

6. Auxiliary proximity sensor (SF)

7. Initial position proximity sensor $(\mathrm{S} 0)$

8. Gear to rotate table

9. Bipolar DC stepper motor (MI)

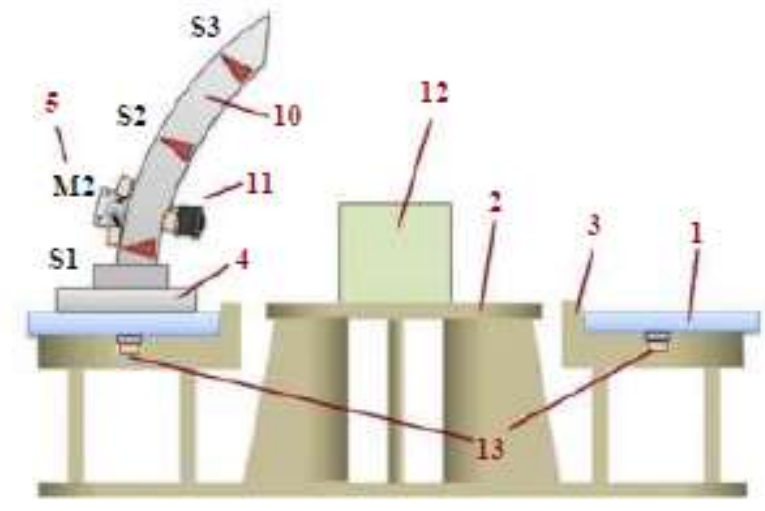

b) Frontal view of the machine.

10. Rail for moving up and down the camera

11. Stereo camera and support structure

12. Object to be digitized

13. Bearings where the table rests

S1, S2, S3. Proximity sensors for placing the camera at three different heights

S4. Proximity sensor to detect obstructions in front of the camera.

Figure 2 Views and components of the proposed image acquisition machine

Source: Own Elaboration

\subsection{Electronic design and control of the machine}

A DRV8825 driver is used to control the M1 and M2 motors. The DIR direction at which the motor rotates is controlled by a PLC; to send the pulses and move the motors, a signal is used to enable an external pulse generator connected to the driver. For the interface between the PLC and the external circuits, STEP-DOWN converters are used to step down from $24 \mathrm{~V}$ to $5 \mathrm{~V}$ or $3.3 \mathrm{~V}$, and STEP-UP converters are used for the opposite action. The external pulse generation circuits send to the PLC a FC signal for each motor, indicating that the frequency is within a suitable range to start operation; these are necessary conditions to go to the initial state.

To measure the speed of the M1 motor, an array of magnets is placed in its attached gear; a Hall effect sensor is used as a magnetic field detector to detect each magnet as it passes through the sensor, generating a train of pulses with which the revolutions per minute can be obtained (Doan, 2020). If the speed is too high or too low, signals are sent so that a visual alarm can be generated. Table 1 presents the signals used in the electronic design and control of the machine. This table describes the input and output signals used for control employing a PLC. 
In the input signals, the origin indicates where the signals come from. In the output signals the destination indicates where the signals go.

\begin{tabular}{|c|c|c|c|}
\hline Inputs & Type & Description & Origin \\
\hline INI & BOOL & start auto sequence & button \\
\hline ESTOP & BOOL & emergency stop & switch \\
\hline AUT & BOOL & automatic mode & selector \\
\hline HOME & BOOL & set motors to home & button \\
\hline FC_M1 & BOOL & $\begin{array}{l}\text { suitable motor } \\
\text { frequency indicator } \\
\text { of motor M1 }\end{array}$ & ATTINY85 1 \\
\hline FC_M2 & BOOL & $\begin{array}{l}\text { suitable frequency } \\
\text { indicator of motor } \\
\text { M2 }\end{array}$ & ATTINY85 2 \\
\hline VMAX_M1 & BOOL & $\begin{array}{l}\text { very high M1 motor } \\
\text { speed indicator }\end{array}$ & ATTINY85 1 \\
\hline VMIN_M1 & BOOL & $\begin{array}{l}\text { very low M1 motor } \\
\text { speed indicator }\end{array}$ & ATTINY85 1 \\
\hline So & BOOL & $\begin{array}{l}\text { starting position of } \\
\text { motor M1 }\end{array}$ & proximity sensor \\
\hline SF & BOOL & $\begin{array}{l}\text { auxiliary sensor to } \\
\text { move motor M1 }\end{array}$ & proximity sensor \\
\hline S1 & BOOL & $\begin{array}{l}\text { bottom rail position } \\
\text { of motor M2 }\end{array}$ & proximity sensor \\
\hline S2 & BOOL & $\begin{array}{l}\text { middle rail position } \\
\text { of motor } \mathrm{M} 2\end{array}$ & proximity sensor \\
\hline S3 & BOOL & $\begin{array}{l}\text { upper rail position } \\
\text { of motor M2 }\end{array}$ & proximity sensor \\
\hline S4 & BOOL & $\begin{array}{l}\text { obstruction of the } \\
\text { camera }\end{array}$ & proximity sensor \\
\hline mDIS_M1 & BOOL & disable motor M1 & switch \\
\hline mDIR_M1 & BOOL & $\begin{array}{l}\text { direction of motor } \\
\text { M1 }\end{array}$ & switch \\
\hline mGP_M1 & BOOL & $\begin{array}{l}\text { enable pulse } \\
\text { generator for motor } \\
\text { M1 }\end{array}$ & switch \\
\hline mDIS_M2 & BOOL & disable motor M2 & switch \\
\hline mDIR_M2 & BOOL & $\begin{array}{l}\text { direction of motor } \\
\text { M2 }\end{array}$ & switch \\
\hline mGP_M2 & BOOL & $\begin{array}{l}\text { enable pulse } \\
\text { generator for motor } \\
\text { M2 }\end{array}$ & switch \\
\hline MS0_M1 & BOOL & $\begin{array}{l}\text { micro-step } \\
\text { configuration of } \\
\text { motor M1 }\end{array}$ & $\begin{array}{l}\text { pin MS0, driver } \\
\text { motor M1 }\end{array}$ \\
\hline MS1_M1 & BOOL & $\begin{array}{l}\text { micro-step } \\
\text { configuration of } \\
\text { motor M1 }\end{array}$ & $\begin{array}{l}\text { pin MS1, driver } \\
\text { motor M1 }\end{array}$ \\
\hline MS2_M1 & BOOL & $\begin{array}{l}\text { micro-step } \\
\text { configuration of } \\
\text { motor M1 }\end{array}$ & $\begin{array}{l}\text { pin MS2, driver } \\
\text { motor M1 }\end{array}$ \\
\hline MS0_M2 & BOOL & $\begin{array}{l}\text { micro-step } \\
\text { configuration } \\
\text { motor M2 }\end{array}$ & $\begin{array}{l}\text { pin MS0, driver } \\
\text { motor M2 }\end{array}$ \\
\hline MS1_M2 & BOOL & $\begin{array}{l}\text { micro-step } \\
\text { configuration } \\
\text { motor M2 }\end{array}$ & $\begin{array}{l}\text { pin MS1, driver } \\
\text { motor M2 }\end{array}$ \\
\hline MS2_M2 & BOOL & $\begin{array}{l}\text { micro-step } \\
\text { configuration } \\
\text { motor M2 }\end{array}$ & $\begin{array}{l}\text { pin MS2, driver } \\
\text { motor M2 }\end{array}$ \\
\hline DIS_M1 & BOOL & disable motor M1 & $\begin{array}{l}\text { pin EN, driver } \\
\text { motor M1 }\end{array}$ \\
\hline DIR_M1 & BOOL & $\begin{array}{l}\text { direction of motor } \\
\text { M1 }\end{array}$ & \begin{tabular}{|l|} 
pin DIR, driver \\
motor M1 \\
\end{tabular} \\
\hline GP_M1 & BOOL & $\begin{array}{l}\text { enable pulse } \\
\text { generator for motor } \\
\text { M1 }\end{array}$ & ATTINY85 1 \\
\hline DIS_M2 & BOOL & disable motor M2 & \begin{tabular}{|l|} 
pin EN, driver \\
motor M2 \\
\end{tabular} \\
\hline DIR_M2 & BOOL & $\begin{array}{l}\text { direction of motor } \\
\text { M2 }\end{array}$ & $\begin{array}{l}\text { pin DIR, driver } \\
\text { motor M2 } \\
\end{array}$ \\
\hline GP_M2 & BOOL & $\begin{array}{l}\text { enable } \\
\text { generator for } \text { M2 } \\
\text { motor }\end{array}$ & ATTINY85 2 \\
\hline CRIT & BOOL & alarm signal & LED \\
\hline
\end{tabular}

Table 1 PLC input and output signals Source: Own elaboration

ISSN 2523-6814

ECORFAN® All rights reserved
Figures 3 and 4 show the PLC operation logic. Figure 3 shows the PLC operation modes; Figure 4 presents the main GRAFCET diagram, which was designed following the GEMMA guide (Urrego, 2011).

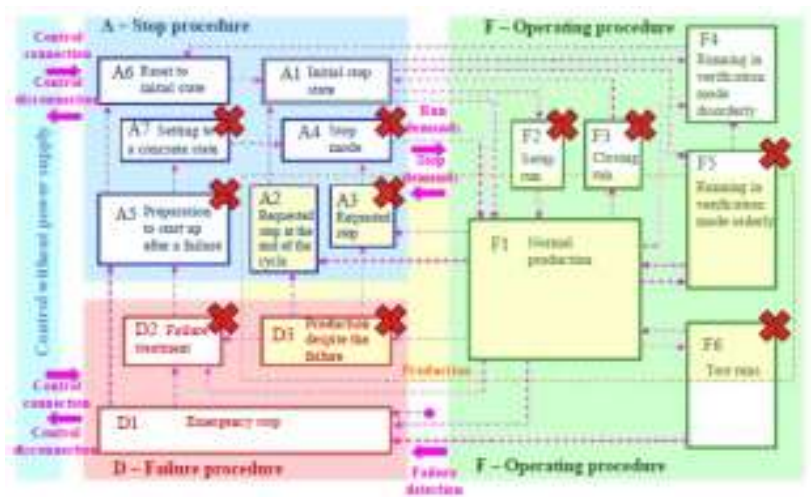

Figure 3 PLC operation modes Source: CITCEA, 2021

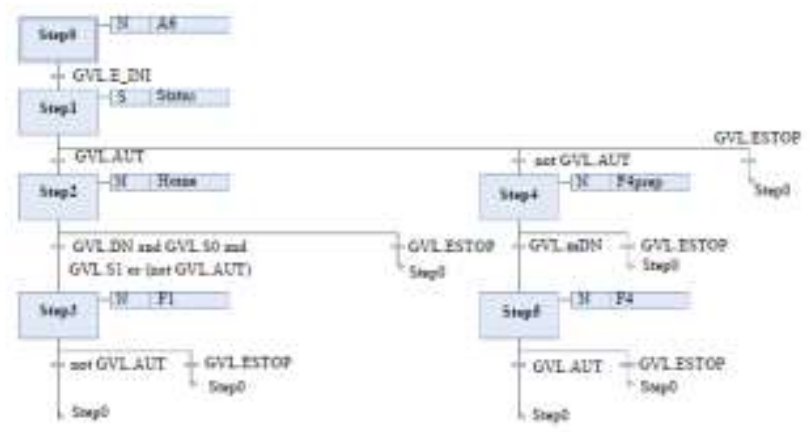

Figure 4 Main GRAFCET diagram Source: Own Elaboration

The block diagram in Figure 3 shows a recommendation based on the GEMMA guide of different operating modes that an automation system can have depending on the combinations of input signals. It also defines how to switch from one operating mode to another (CITCEA, 2021). This diagram is used to visualize which modes of operation are relevant for the functionality required by the machine. Blocks with no cross marks were considered for the operation of the proposed image acquisition machine. The contemplated operation modes are: A1 initial stop state, F1 automatic operation, F4 manual operation, D1 emergency stop, and A6 reset to initial state.

The GRAFCET diagram presented in Figure 4 consists of 6 steps. Step0 is where the machine is reset to the initial state. In Step1, the verification of the speed of the motors is initiated, which allows displaying an alarm when speed limits are exceeded. Step2 is used to set the camera to the HOME position. It should be noted that the operation of the machine can be manual or automatic.

CORONA-PATRICIO, Cesar Agustin \& RETA, Carolina. Design of the operation of a rotating machine for the acquisition of multi-view stereoscopic images for the $3 \mathrm{D}$ reconstruction of objects. Journal of Computational Technologies. 2021 
During Step3, the operation is automatic. During Step5, the operation is manual. Step4 is a preparation stage to enter manual mode. An emergency stop can be set at any time, where the machine is sent back to the initial state.

Note in Figure 4 the logic of the Boolean operations, which determines the state of the transitions of the GRAFCET diagram and allows controlling the different stages of the machine. The signals used in these operations have been presented in Table 1.

It is worth noting that GRAFCET diagrams made for each step (Step 0 - Step 5) describe the operation of the PLC. These diagrams are presented in the Appendix Section.

\section{Results}

A simulation was carried out in CODESYS software (3S-Smart Software Solutions GmbH., 2021) using a virtual PLC to verify the operation of the logic described in the GRAFCET diagram in Figure 4. A graphical interface was developed in the same software to carry out the simulation. This interface is presented in Figure 5; Section 3.1 presents more details of the interface. The proposed machine will allow acquiring a sequence of images from different viewpoints considering different elevation levels. A sample of the results that can be obtained with the proposed machine are presented in Section 3.2.

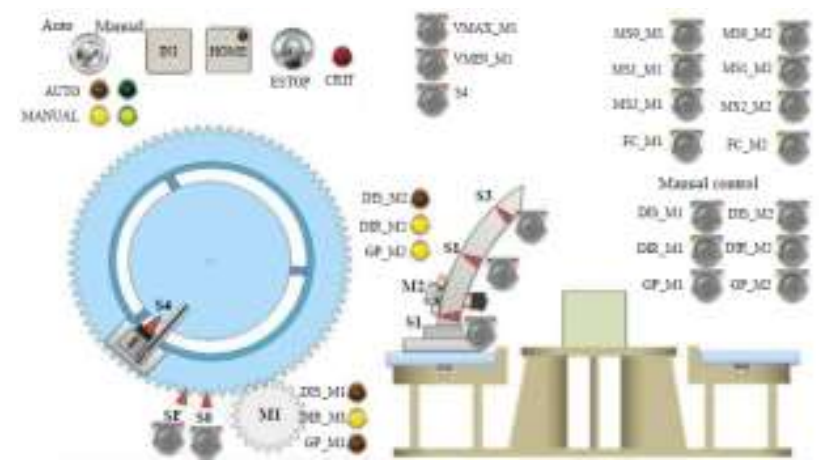

Figure 5 Graphical interface for machine operation Source: Own Elaboration

\subsection{Graphical interface for machine operation}

Figure 5 shows the interface developed to validate the operation of the machine. The status of the input signals can be changed using buttons. The status of the output signals are displayed with LED indicators.
The simulation performed with this interface helped to verify the correct operation of the machine's manual, automatic, and emergency stop modes. At the start, the machine is in either manual or automatic mode, which is determined by the AUT selector. The image capture sequence is initiated by pressing the INI start button. In manual mode, switches are used to freely move the motors and control their rotation direction.

In automatic mode, the camera is first brought to an initial HOME position. From there, the well-defined capture sequence starts. If the emergency stop is activated, the motors are stopped but kept energized to maintain torque and prevent damage to the camera if it falls from the highest position.

\subsection{Visual results of the image acquisition process}

A sample of the results that can be obtained with the proposed machine is presented in Figure 6. The shown images are synthetic, created using Blender software (Community, B. O, 2021) to exemplify the acquisition from different points of view, considering three elevation levels.

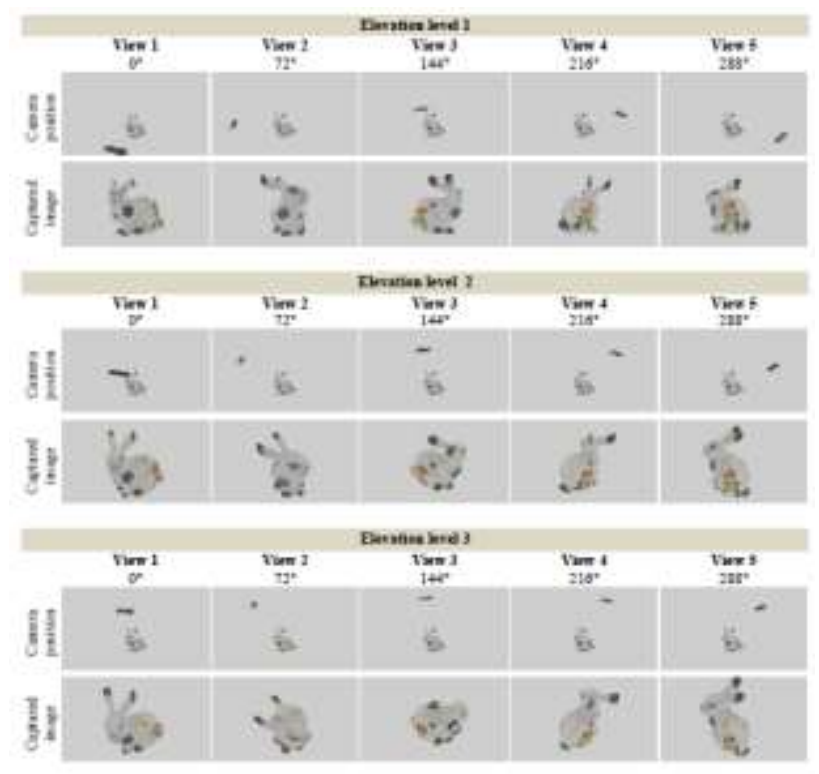

Figure 6 Visual representation of the acquisition process Source: Own elaboration based on model of Zou, 2011

In Figure 6, the images are organized into three elevation levels. Each elevation level has five views. In each view, images are shown for both the camera position and the image captured from that position. 
The views are obtained by rotating the camera around the object with equal increments of $72^{\circ}$ between each view, where view 1 is the starting position at $0^{\circ}$ at each level.

\section{Appendix}

This section presents a description of the 6 stages of the image acquisition process of the proposed machine (illustrated in Figure 4 in Section 2.2) and the GRAFCET diagrams generated for each stage of the process.

Figure 7 shows the initial setup, in which the drivers are configured to work with microsteps. The motors are enabled to maintain torque, and the necessary signals are reset to stop them in their last position.

Figure 8 shows a visual alarm. It is activated when the speed limits are exceeded or when a strange object is detected with the S4 sensor in front of the camera.

Figure 9 shows the process of going to the HOME position. First, the motor M2 is sent back to the bottom position of the rail. Then the motor M1 is brought to the HOME position, where sensor SF is deactivated and sensor S0 is activated.

Figure 10 shows the automatic control of the machine operation. From the HOME position, the table is rotated $360^{\circ}$. At the end of the rotation, the camera is raised until it reaches sensor S2. Then, the table is rotated $360^{\circ}$, and the process is repeated until the camera has risen to $\mathrm{S} 3$. At the end of the sequence, the machine is sent back to the HOME position and returns to the initial state waiting response of the INI start button.

Figure 11 shows the manual mode of the machine. Figure 11a shows the operation logic in manual mode. Figure $11 \mathrm{~b}$ shows the initial conditions that allow the execution of the manual mode.

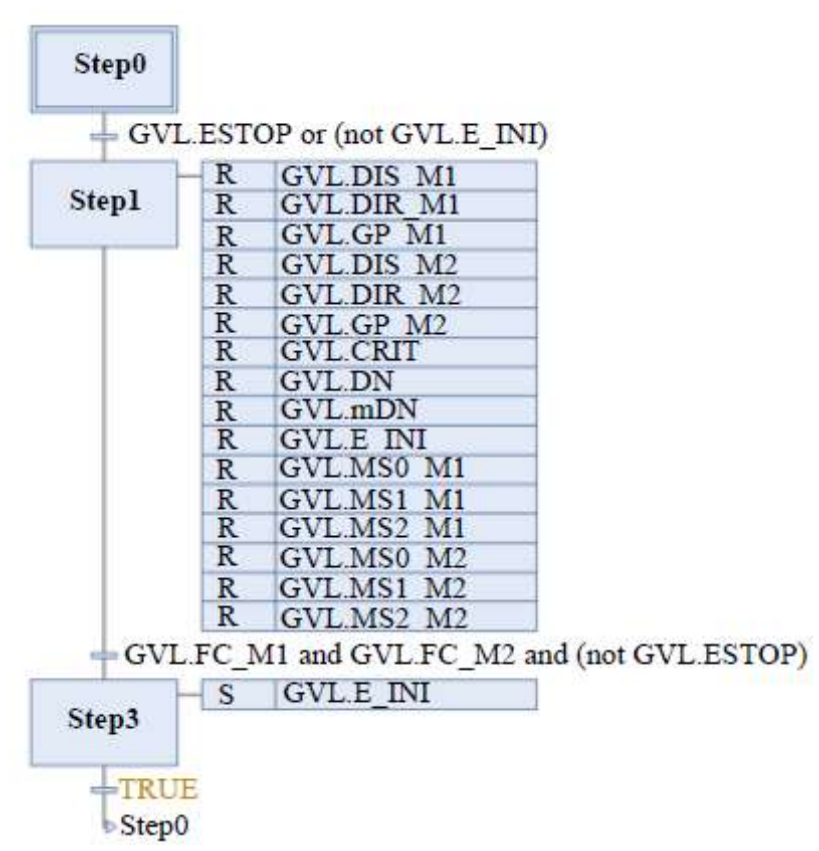

Figure 7 Initial state

Source: Own Elaboration

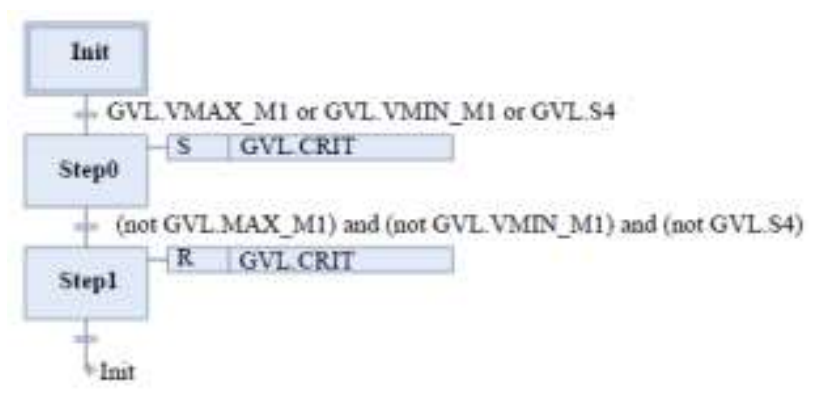

Figure 8 Visual alarm. Source: Own Elaboration

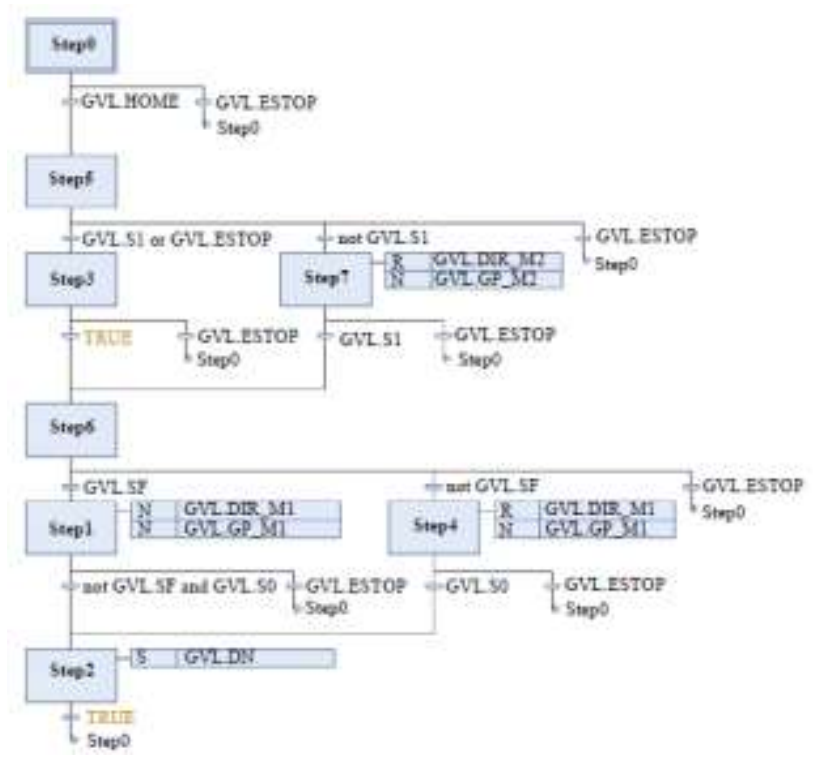

Figure 9 Return to initial position Source: Own Elaboration 


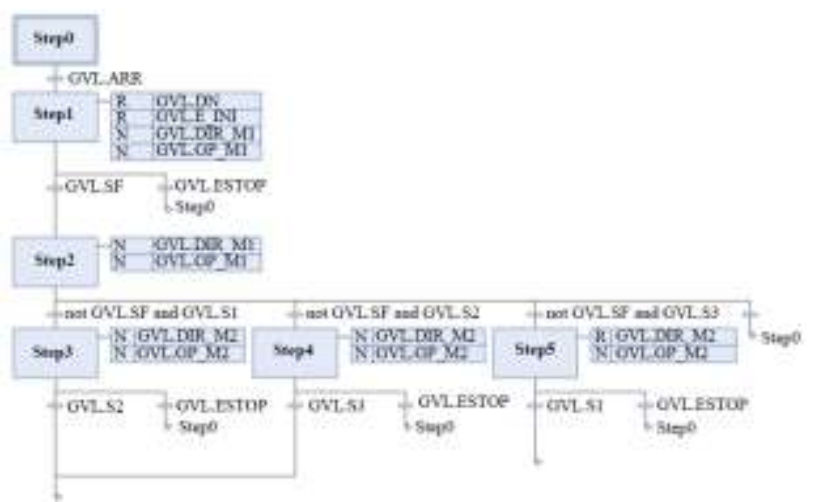

Figure 10 Operation in automatic mode Source: Own Elaboration

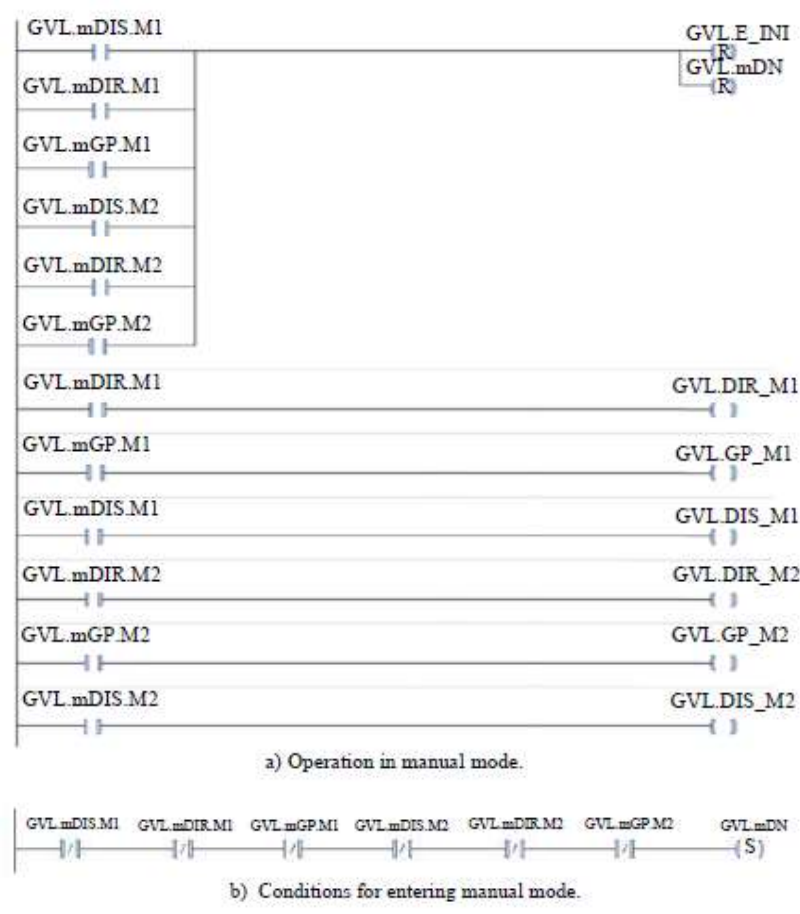

Figure 11 Manual mode Source: Own Elaboration

\section{Conclusions}

This paper proposes a machine that allows the acquisition of images for a reconstruction process based on multiple views, where the object to be digitized is kept fixed, and the camera rotates around it. All the necessary components for its operation were defined as well as different operation modes and the programming logic of a virtual PLC to control it. A graphical interface was developed to simulate the operation of the proposed machine.

The simulation allowed verifying the operation of the manual and automatic operation modes and the conditions for emergency stop. An automated image capture sequence was proposed, which allows the camera to capture images at equally spaced intervals at three elevation levels.
The visual sample images of the acquisition process demonstrate that, with the proposed capture sequence, it is possible to collect images of the entire visible surface of the object, except for its base, since views are obtained from all around the object and at different heights.

As future work, the physical construction of the machine is proposed, defining the necessary materials and its dimensions. It is also suggested to propose techniques for the reconstruction of objects using the images acquired with this machine, as well as to explore opportunities for improvement by replacing the PLC with a microcontroller or an SBC card.

\section{References}

Allice Vision (2021). Meshroom: open-source 3D Reconstruction Software based on the AliceVision framework. Retrieved from https://alicevision.org/

CITCEA. (2021). Descripción de la guía GEMMA. Universidad Politécnica de Catalunya, España. Retrieved from https://recursos.citcea.upc.edu/grafcet/gemma/d escrip.html

Collins, T., Woolley, S., Gehlken, E., \& Ch'ng, E. (2019). Automated Low-Cost Photogrammetric Acquisition of 3D Models from Small Form-Factor Artefacts. Electronics, 8 , 1441.

https://doi.org/10.3390/electronics8121441

Community, B. O. (2021). Blender - a 3D modelling and rendering package. Stichting Blender Foundation, Amsterdam. Retrieved from http://www.blender.org

Cordes, K., Scheuermann, B., Rosenhahn, B., \& Ostermann, J. (2012). Occlusion Handling for the Integration of Virtual Objects into Video. https://doi.org/10.13140/2.1.4896.4808

Deris, A., Trigonis, I., Aravanis, A., \& Stathopoulou, E. (2017). DEPTH CAMERAS ON UAVs: A FIRST APPROACH. ISPRS International Archives of the Photogrammetry, Remote Sensing and Spatial Information Sciences, XLII-2/W3, 231-236. https://doi.org/10.5194/isprs-archives-XLII-2W3-231-2017 
Doan, M., Kai, Y., \& Obi, S. (2020). Twin Marine Hydrokinetic Cross-Flow Turbines in Counter Rotating Configurations: A LaboratoryScaled Apparatus for Power Measurement. Journal of Marine Science and Engineering, 8, 918. https://doi.org/10.3390/jmse8110918

Durou, J.-D., Falcone, M., Quéau, Y., \& Tozza, S. (2020). A Comprehensive Introduction to Photometric 3D-Reconstruction. Advances in Photometric 3D-Reconstruction (pp. 1-29). Springer International Publishing. https://doi.org/10.1007/978-3-030-51866-0_1

Emmitt, J., Mackrell, T., \& Armstrong, J. (2021). Digital Modelling in Museum and Private Collections: A Case Study on Early Italic Armour. Journal of Computer Applications in Archaeology, 4, 63-78. https://doi.org/10.5334/jcaa.63

Evgenikou, V., \& Georgopoulos, A. (2015). Investigating $3 \mathrm{D}$ reconstruction methods for small artifacts. ISPRS - International Archives of the Photogrammetry, Remote Sensing and Spatial Information Sciences, XL-5/W4, 101108. https://doi.org/10.5194/isprsarchives-XL5-W4-101-2015

Kai-Browne, A., Kohlmeyer, K., Gonnella, J., Bremer, T., Brandhorst, S., Balda, F., Plesch, S., \& Lehmann, D. (2016). 3D Acquisition, Processing and Visualization of Archaeological Artifacts. 397-408. https://doi.org/10.1007/9783-319-48496-9_32

Li, W., Xiao, X., \& Hahn, J. (2019). 3D Reconstruction and Texture Optimization Using a Sparse Set of RGB-D Cameras. 2019 IEEE Winter Conference on Applications of Computer Vision (WACV).

https://doi.org/10.1109/WACV.2019.00155

OpenScan (2021). DIY 3D Scanner. Retrieved from https://en.openscan.eu

OpenSFM (2021). OpenSFM: An open-source Structure from Motion library that lets you build 3D models from images. Retrieved from https://www.opensfm.org/

Regard3D (2021). Regard3D: a free and open source structure-from-motion program. Retrieved from https://www.regard3d.org/
Sheng, B., Zhao, F., Yin, X., Zhang, C., Wang, H., \& Huang, P. (2018). A Lightweight Surface Reconstruction Method for Online 3D Scanning Point Cloud Data Oriented toward 3D Printing. Mathematical Problems in Engineering, 2018, e4673849.

https://doi.org/10.1155/2018/4673849

Stanford University (2014). The Stanford 3D Scanning Repository. Retrieved from http:/graphics.stanford.edu/data/3Dscanrep/\#bu nny

3S-Smart Software Solutions GmbH. (2021). CODESYS. Retrieved from https://www.codesys.com

Urrego, L. (2011). GEMMA Una Herramienta Universal para la Automatización de Procesos. Ingenium, 12, 80-96.

Yilmaz, O., \& Karakus, F. (2013). Stereo and kinect fusion for continuous 3D reconstruction and visual odometry. 2013 International Conference on Electronics, Computer and Computation (ICECCO), 115-118. https://doi.org/10.1109/ICECCO.2013.6718242

Yücer, K., Sorkine-Hornung, A., Wang, O., \& Sorkine-Hornung, O. (2016). Efficient 3D Object Segmentation from Densely Sampled Light Fields with Applications to 3D Reconstruction. ACM Transactions on Graphics, 35(3), 1-15. https://doi.org/10.1145/2876504

Wang, F., \& Hauser, K. (2019). In-hand Object Scanning via RGB-D Video Segmentation. 2019 International Conference on Robotics and Automation (ICRA), 3296-3302. https://doi.org/10.1109/ICRA.2019.8794467

Wu, J., Chen, H., Liu, X., Cao, L., Peng, X., \& Jin, G. (2019). Unsupervised texture reconstruction method using bidirectional similarity function for 3-D measurements. Optics Communications, 439, 85-93. https://doi.org/10.1016/j.optcom.2019.01.051

Zou, K. (2011). Texturemontage Textured Models. Zhejiang University. Retrieved from http://www.kunzhou.net/tex-models.htm 